\title{
Phosphorus Response Efficiency in Cowpea Genotypes
}

\author{
Olaleye Oladiran (Corresponding author) \\ Spices Improvement Programme, National Horticultural Research Institute (NIHORT) Ibadan Nigeria \\ P.M.B. 5432 Idi-Ishin, Ibadan, Oyo-State, Nigeria \\ Tel: 234-802-718-9254 E-mail: oladiran03@yahoo.com
}

Fagbola Olajire

Department of Agronomy, University of Ibadan, Ibadan, Nigeria

E-mail: fagbola8@yahoo.co.uk

\begin{abstract}
Abaidoo Robert C.
Soil Microbiology Unit, International Institute of Tropical Agriculture (IITA)

P.M.B 5320, Ibadan, Nigeria

Ikeorah Nnenna

Department of Agronomy, University of Ibadan, Ibadan, Nigeria
\end{abstract}

$\begin{array}{lc}\text { Received: April 1, } 2011 & \text { Accepted: April 15, } 2011 \quad \text { Online Published: December 1, } 2011 \\ \text { doi:10.5539/jas.v4n1p81 } & \text { URL: http://dx.doi.org/10.5539/jas.v4n1p81 }\end{array}$

The research is sponsored by the International Institute of Tropical Agriculture, (IITA) Ibadan

\begin{abstract}
Phosphorus is important for cowpea production and is inherently low in many tropical soils. Selection of cowpea genotypes that produce good yield under low soil P or those with high P response efficiency can be a low input approach in solving this problem. Therefore, the effect of root architecture and $\mathrm{P}$ application on the yield of cowpea and its $P$ uptake were investigated. A screen house experiment was conducted at the International Institute of Tropical Agriculture (IITA) Ibadan, Nigeria. Three hundred cowpea genotypes obtained from the germplasm collection Unit of IITA were screened for number of root whorls and total number of roots using a completely randomized design with 12 replicates. Ten cowpea genotypes were further selected from the initial screening to determine the effect of three levels of $\mathrm{P}\left(0,20\right.$ and $40 \mathrm{mg} \mathrm{P} \mathrm{kg}^{-1}$ soil) application on their growth and nutrient uptake. The experiment was replicated three times. Phosphorus application significantly $(p<0.05)$ enhanced shoot and root dry weight, total biomass, number of nodules, nodules dry weight, $\mathrm{N}$ and $\mathrm{P}$ uptake of the cowpea genotypes investigated. Six cowpea genotypes exhibited increases in nodules dry weight with $\mathrm{P}$ application. There was no significant relationship between root architecture and $\mathrm{P}$ uptake $(\mathrm{r}=-0.13)$. The $\mathrm{N}$ and $\mathrm{P}$ uptake were enhanced by the application of $\mathrm{P}$ in the cowpea genotypes studied. In low P soil, IT97K-414-5 was efficient in $\mathrm{P}$ uptake and IT92KD-267-2 was efficient in N uptake. The two genotypes may produce cowpea lines suitable in low $P$ soils when used as breeder lines.
\end{abstract}

Keywords: Cowpea genotypes, Phosphorus response efficiency, Root architecture, Nutrient uptake

\section{Introduction}

Cowpea (Vigna unguiculata L. Walp) is a grain legume belonging to the family leguminosae. Its value lies in its high protein content and ability to tolerate drought. It also possesses the ability to fix atmospheric nitrogen through its nodules and thereby grows well in poor soils. Cowpea has been identified as one of the keys to crop-livestock 
integration in the Sahelian region of Nigeria because of its drought tolerance, growth habit in sandy soils, its contribution to soil fertility improvement and its usefulness as food and fodder(Singh, 1999).

Phosphorus is one of the most needed elements for crop production in many tropical soils. However, many tropical soils are deficient in P (Adetunji, 1995). The deficiency can be so acute in some soils that plant growth ceases as soon as the P stored in the seed is exhausted (Mokwunye et al., 1986). Soil P deficiencies primarily results from either inherent low levels of soils $\mathrm{P}$ or depletion of the $\mathrm{P}$ through cultivation. For sustainable food production to meet the increasing population in developing countries, the need for $P$ fertilizer application is expected to increase (Brynes and Bumb, 1998). However, even when P fertilizers are applied to replenish soil fertility, about seventy to ninety percent of the $\mathrm{P}$ fertilizers are adsorbed and becomes locked in various soil $\mathrm{P}$ compounds of low solubility without giving any immediate consideration to crop production (Holford, 1997). Acquisition of P fertilizer by crops depends on soil and plant properties. Plants have evolved properties contributing to a more efficient use of available soil $\mathrm{P}$ and to mobilize $\mathrm{P}$ from less available soil $\mathrm{P}$ fractions. One of the properties evolved by plants in response to $\mathrm{P}$ availability is the modification of their root architecture. New crop varieties with improved root traits that are able to unlock and absorb $\mathrm{P}$ from bound soil $\mathrm{P}$ resources may be of additional value for increasing the efficiency of utilization of applied fertilizer (Abelson, 1999).

Genotypic differences in the effects of P on nodulation (Ankomah et al., 1995) and yield (Jain et al., 1986; Tenebe et al., 1995; Sanginga et al., 2000) of cowpea have been reported previously. However, mechanisms by which these cowpea varieties exhibit differential abilities to grow at low or high P supply are not completely understood. A better understanding of cowpea varietal differences in $P$ nutrition may help in breeding new lines for areas where fertilizers are scarce and expensive. Therefore, this study was aimed at determining the effects of root architecture and $\mathrm{P}$ application on the yield of cowpea and its $\mathrm{P}$ uptake were investigated

\section{Materials and Method}

\subsection{Screening of Cowpea Genotypes for Variability in Number of Root Whorls}

The experiment was conducted at the International Institute of Tropical Agriculture (IITA) screen house between July and September 2007. The annual temperature ranges from $21^{\circ} \mathrm{C}$ to $30^{\circ} \mathrm{C}$ while the mean annual temperature was $28.1^{\circ} \mathrm{C}$. The experimental design used was completely randomized design (CRD). Three hundred cowpea genotypes were used and each genotype was replicated twelve times.

Beach sand collected from Lagos was acid-washed with concentrated hydrogen tetraoxosulphate VI acid $\left(\mathrm{H}_{2} \mathrm{SO}_{4}\right)$ to remove the organic materials present in the sand and to reduce the salt content. A litre of $\mathrm{H}_{2} \mathrm{SO}_{4}$ was applied to $20 \mathrm{~kg}$ of sand in 12 litres of water and left for 48 hours. The mixture was later rinsed with tap water until the $\mathrm{pH}$ of the sand was between 6 and 7. Two-hundred and fifty gram soil was weighed into the cup. The cowpea seeds were sown directly into the cups with four seeds sown per cup. The plants were terminated on the fifth day (seedling stage). The shoot was cut off at the soil surface and root carefully removed. The data collected were the number of root whorls per plant and the number of lateral root per whorl.

\subsection{Effects of Phosphorus on Cowpea Genotypes}

The experiment was conducted at the screen house of IITA between October and November 2007 using completely randomized design and the treatments replicated three times. It was a factorial experiment with two factors, $\mathrm{P}$ application at 3 levels $\left(0,20\right.$ and $40 \mathrm{mgkg}^{-1}$ soil) and 10 cowpea genotypes IT92KD--405-2, IT85D-3334-1, IT97K-414-5, IT98K-205-9, IT86D-330, IT93K-573-1, IT92KD-279-3， IT93K-2045-29, IT92KD-267-2 and IT93KZ-4-3-1-7. The genotypes were selected based on the screening in the first experiment. Five genotypes (first five) were randomly selected from those with high number of root whorls and the last five from those with low number of root whorls.

Subsoil $(20$ to $40 \mathrm{~cm}$ ) was collected from IITA-Ibadan and analyzed for macro and micronutrients. The subsoil was mixed with acid washed beach sand in the ratio of $1: 1$ and $2.5 \mathrm{~kg}$ of the mixture weighed into the pot for planting.

Four seed were sown per pot and later thinned to two seven days after germination.

\subsection{Preparation and Application of the Nutrient Solution}

Modified Jensen's nutrient solution (P free) was prepared as follows: the solution consists of stock solution I and II prepared separately. Solution I consists of $20 \mathrm{~g} \mathrm{MgSO}_{4} .7 \mathrm{H}_{2} \mathrm{O}, 20 \mathrm{~g} \mathrm{NaCl}, 10 \mathrm{~g} \mathrm{FeCl}_{3}, 0.25 \mathrm{~g} \mathrm{KNO}_{3}$ and distilled water to make up to one liter. Solution II consists of $2.86 \mathrm{~g} \mathrm{H}_{3} \mathrm{BO}_{3}, 1.81 \mathrm{~g} \mathrm{MnCl}_{2} .4 \mathrm{H}_{2} \mathrm{O}, 0.22 \mathrm{~g} \mathrm{ZnSO}_{4} .7 \mathrm{H}_{2} 0,0.08$ $\mathrm{g} \mathrm{CuSO}_{4} .5 \mathrm{H}_{2} \mathrm{O}, 0.25 \mathrm{~g} \mathrm{NaMoO}_{4} .2 \mathrm{H}_{2} \mathrm{O}$ and distilled water to make up to one litre. To prepare 10 liters of nutrient 
solution, $100 \mathrm{ml}$ of solution I was added to $10 \mathrm{ml}$ of solution II and distilled water to make up to 10 litres. The stock solution of $\mathrm{P}$ was prepared by dissolving $136.09 \mathrm{~g}$ of $\mathrm{KH}_{2} \mathrm{PO}_{4}$ in 1 litre of distilled water in a volumetric flask.

The nutrient solution was applied a week after planting and at subsequent weeks with the application of distilled water in between because of the problem of salt accumulation. The P solution was also applied a week after planting.

The plants were sprayed as at when required to prevent insect infestation with a mixture of 3 mls Sherpa plus 280 EC (30 g/l cypermethrin and $250 \mathrm{~g} / \mathrm{l}$ dimethoate as a water emulsifiable concentrate) and $1 \mathrm{ml}$ of dimethoate $40 \%$ EC (a.i. 0-dimethyl S-methylcarbamoylmethyl phosphorodithioate $40 \% \mathrm{WW}$ ) making it up with water to one litre in a calibrated sprayer. Harvesting was done six weeks after sowing. The plant samples were oven-dried at a temperature of $65^{\circ} \mathrm{C}$ after which the shoot was milled and analyzed for $\mathrm{N}$ and $\mathrm{P}$ content in the laboratory using auto-analyzer.

\subsection{Data Collection and Statistical Analysis}

Data were collected on root dry weight, shoot dry weight, total biomass, root whorls and their lateral root, number of nodules, nodules dry weight, nitrogen and P content of the shoot, nitrogen and phosphorus uptake of the plant. Analysis of variance was carried out on data using SAS PROC GLM (2003) and the means were separated using LSD.

\section{Results and Discussion}

\subsection{Physical and chemical properties of the subsoil}

The subsoil used for the study was slightly acidic and low in organic matter (Table 1). The macro elements were below the critical levels required for the proper growth and development of cowpea. This indicates that the soil was depleted. The textural classification of the soil is loamy sand (Table 1).

\subsection{Variation in the number of root whorls of the cowpea genotypes}

Genotypic differences occurred in the number of whorls and total number of root of the 300 cowpea genotypes screened. All the 300 cowpea genotypes had a negatively skewed distribution pattern in the number of root whorls and were distributed into eight classes (Figure 1). The root whorl numbers ranged between 2 and 6 with $32 \%$ of the genotypes having an average number of root whorl between 3.0 and 3.49. Seventeen percent of the genotypes were below the modal class while forty-five percent were above the modal class. The numbers of genotypes with number of root whorls above 5 were 4 while those below 2.5 were 5 . This agrees with the findings of Roman-Aviles et al., (2004) who reported a marked difference in adventitious rooting of genotypes, which varied from $4-43$ adventitious roots per plant among the bean genotypes screened in the field, and $0-8$ adventitious roots per plant under green house conditions. Leon and Schwang (1992), Romer et al., (1988), and Atkinson (1991) had also reported large differences in root morphology and distribution between genotypes of plant species.

\subsection{Effect of $P$ on the shoot and root dry weight of the cowpea genotypes}

The shoot dry weight and root dry weight for genotypes were not significantly different from each other. Only the application of $40 \mathrm{mg} \mathrm{P} \mathrm{kg}^{-1}$ soil significantly increased the shoot and root dry weight (Table 2). With the application of 0 and $20 \mathrm{mg} \mathrm{P} \mathrm{kg}^{-1}$ soil, shoot dry weight was significantly lower when compared to the application of $40 \mathrm{mg} \mathrm{P} \mathrm{kg}^{-1}$ soil. All the genotypes with the exception of IT92KD--405-2 and IT93KZ-4-3-1-7 had increases in the shoot dry weight with increased $\mathrm{P}$ application. For the root dry weight, there was a significant difference $(\mathrm{p}<0.05)$ between the application of 0 and $40 \mathrm{mg} \mathrm{Pg}^{-1}$ soil. Although, there was no interaction between genotypes and $\mathrm{P}$ rates, an increase of more than $100 \%$ was observed in the root dry weights of IT92KD-405-2 and IT95K-2045-29 (Table 2).

\subsection{Effect of $P$ on the number of nodules and the nodules dry weight}

The application of $\mathrm{P}$ at $40 \mathrm{mg} \mathrm{P} \mathrm{kg}^{-1}$ soil significantly increased the number of nodules in all the cowpea genotypes studied, however the number of nodules was not significantly influenced by genotype. The increase in number of nodules as the P rate applied increases confirms the findings of Luse et al., (1975); Agboola and Obigbesan (1977), where they reported increases in the number of nodules in cowpea due to $\mathrm{P}$ application. IT97K-414-5, IT98K-205-9 and IT86D-330 did not nodulate under $0 \mathrm{mg} \mathrm{P} \mathrm{kg}^{-1}$ soil (Table 3), this indicates that $\mathrm{P}$ is essential for nodule formation in cowpea.

The genotypes were significantly different from each other $(p<0.05)$ with reference to nodules dry weight (Table 3). There was a highly significant interaction between the genotypes and the P rates under nodules dry weight which suggests that some genotypes are able to use P more efficiently than others. The genotypes exhibit differential responses in nodules dry weight; this is in agreement with the findings of Ankomah et al., (1995), 
where they observed genotypic differences in the effect of P on nodulation. IT92KD-267-2 had significantly higher mean nodule dry weight when compared to other genotypes. The nodule dry weight under P rates applied are also significantly different $(\mathrm{p}<0.001)$ from each other. The nodule dry weight at 0 and $20 \mathrm{mg} \mathrm{P} \mathrm{kg}^{-1}$ soil were significantly lower compared with $40 \mathrm{mg} \mathrm{P} \mathrm{kg}^{-1}$ soil. The nodules dry weight increases with $\mathrm{P}$ application except IT85D-3334-1 and IT92KD-267-2. Although IT85D-334-1 and IT92KD-279-3 had some nodules the nodules dry weight were negligible at $0 \mathrm{mg} \mathrm{P} \mathrm{kg}{ }^{-1}$ soil for the formal and under 0 and $20 \mathrm{mg} \mathrm{P} \mathrm{kg}^{-1}$ soil for the later. IT92KD--405-2 and IT93KZ-4-3-1-7 had higher number of nodules at $0 \mathrm{mg} \mathrm{P} \mathrm{kg}^{-1}$ soil than at $20 \mathrm{mg} \mathrm{P} \mathrm{kg}^{-1}$ but the nodules dry weight were higher at $20 \mathrm{mg} \mathrm{P} \mathrm{kg}^{-1}$ indicating $\mathrm{P}$ response efficiency. The increase in nodules dry weight with P application also confirms the work of Kolawole et al., (2002), where they reported that $60 \%$ of the cowpea lines studied had higher nodules weight with P application.

\subsection{Effect of $P$ on the root architecture of the cowpea genotypes}

Significant genotypic differences $(\mathrm{p}<0.001)$ were observed in the number of root whorls (Table 4). IT92KD-279-3, IT93K-2045-29 and IT92KD-267-2 were significantly lower compared to the other genotypes except IT93K-573-1. The cowpea genotypes with high number of whorl in the first experiment also exhibited high number of whorls in the second experiment. Four out of the ten cowpea genotypes (IT92KD--405-2, IT98K-205-9, IT86D-330 and IT93K-573-1) had the same number of root whorl even with the application of P. There was no significant difference in the number of root whorls under the three different $\mathrm{P}$ rates. Also, there was no interaction between the genotypes and the different P rates. Other genotypes with the exception of IT93K-2045-29 had the highest number of whorls at $0 \mathrm{mg} \mathrm{P} \mathrm{kg}^{-1}$ soil, this suggests that $\mathrm{P}$ application decreases whorl formation in cowpea. However Basu et al., (2007), observed that neither the number of basal roots nor the number of whorls was affected by phosphorus availability, pointing to the fact that basal roots emerge while seedling growth is still dependent on cotyledonary reserves.

Genotype, $\mathrm{P}$ rate and their interaction significantly affected total number of roots (Table 4). P application at 0 and $20 \mathrm{mg} \mathrm{P} \mathrm{kg}^{-1}$ soil were significantly different. IT92KD--405-2, IT85D-3334-1 and IT98K-205-9 had the highest total number of root at $0 \mathrm{mg} \mathrm{P} \mathrm{kg}$-1 soil. When compared with other P rates IT92KD--405-2, IT85D-3334-1, IT98K-205-9 and IT92KD-267-2 had the highest total number of root at $0 \mathrm{mg} \mathrm{P} \mathrm{kg}^{-1}$ soil.

\subsection{Effect of $P$ on the total biomass of the cowpea genotypes}

The total biomass was significantly $(\mathrm{p}<0.001)$ influenced by the application of $\mathrm{P}$. The mean total biomass at $40 \mathrm{mg}$ $\mathrm{P} \mathrm{kg}^{-1}$ was significantly higher than at the other rates of $\mathrm{P}$ applied (Table 5). The genotypes were not significantly different from each other. Also there was no interactive effect between the genotype and $\mathrm{P}$ application.

\subsection{Effect of $P$ on the $N$ and $P$ uptake of the cowpea genotypes}

Application of $\mathrm{P}$ significantly increased the $\mathrm{N}$ uptake (Table 6). The genotypes responded differently to $\mathrm{P}$ application. IT92KD-267-2 had the highest $\mathrm{N}$ uptake. This showed that the genotype had high response efficiency with $\mathrm{P}$ application despite the fact that the $\mathrm{P}$ uptake was not high.

This efficient use of $\mathrm{P}$ could be seen in the number of nodules and the nodules dry weight. The genotype also had the highest mean shoot dry weight. Hence, genotypic differences that occur in nutrient uptake are important determinants of nutrient use efficiency. Marschener, (1998) stated that these differences could be related to root size and morphology and/or root physiology. This is in contrast to the findings in this study because IT92KD-267-2 had low number of whorls and corresponding total number of roots. However, it has been noted that the high P use efficiency of different cover crops, legume species (Horst et al., 2001), L. albus (Gardner and Boundy 1983), cowpea genotypes (Krasilnikoff et al., 2003; Sanginga et al., 2000), and faba bean (Nuruzzaman et al., 2005) could be related to their capability to acquire $\mathrm{P}$ from sparingly available $\mathrm{P}$ sources.

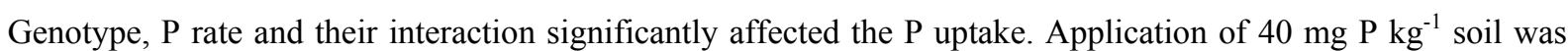
significantly higher than other rates (Table 6). The P uptake among the cowpea genotypes increased with the application rate except for IT85D-3334-1, IT97K-414-5 and IT98K-205-9. The mean P uptake increased significantly with applied $\mathrm{P}$ rate. The increase in $\mathrm{P}$ uptake could result in $\mathrm{N}_{2}$ fixation and this supports the work of Hogh-Jensen et al. (2002), where they reported an improvement in grain legume growth and $\mathrm{N}$ fixation owing to $\mathrm{P}$ application due to the high $\mathrm{P}$ requirement for $\mathrm{N}$ fixation. IT93K-573-1 had the highest $\mathrm{P}$ and $\mathrm{N}$ uptake at $40 \mathrm{mg} \mathrm{P}$ $\mathrm{kg}^{-1}$ soil. This same genotype at $40 \mathrm{mg} \mathrm{P} \mathrm{kg}^{-1}$ soil had the highest shoot dry weight, total biomass, was the second highest in root dry weight as well as nodules dry weight. These suggest that the genotype had good response to $\mathrm{P}$ application. The response of cowpea genotypes to $\mathrm{P}$ application in terms of shoot dry weight, root dry weight, number of nodules, nodules dry weight, $\mathrm{N}$ and $\mathrm{P}$ uptake showed that $\mathrm{P}$ is an important nutrient element affecting the yield of cowpea. This corroborate the findings of Kolawole et al., (2002) where they observed that P fertilizers 
significantly enhanced shoot, root and grain dry weights of cowpea. Okeleye and Okelana (1997) also observed significant increase in nodulation, grain yield and total dry matter for cowpea varieties in response to $\mathrm{P}$ application.

\subsection{Correlation coefficient of the parameters examined}

All the parameters are positively correlated with each other. All the parameters except the $\mathrm{N}$ and $\mathrm{P}$ uptake had a low correlation (Table 7). The N and P uptake had a high positive significant correlation among each other. Total biomass had significant correlation with all other parameters. The root dry weight was not significantly correlated with other parameters except the total biomass. The number of root whorls and total number or root had significant correlation with each other. The total number of root had a low positive correlation with $\mathrm{N}$ uptake but was negatively correlated with $\mathrm{P}$ uptake (Table 8). The number of root whorls had a negative correlation with $\mathrm{N}$ and $\mathrm{P}$ uptake.

\section{Conclusion}

The exploitation of genotypic differences in P acquisition from less available sources by legumes is of concern to scientist in sub Saharan Africa. This is particularly important because of the effect of $\mathrm{P}$ in improving productivity and in enhancing soil fertility through nitrogen fixation. Crop genotypes with greater $\mathrm{P}$ acquisition efficiency would be of great importance in ensuring food security in developing countries, where many regions have low fertility soils and inadequate fertilizer inputs.

IT93K-573-1 had the highest $\mathrm{P}$ and $\mathrm{N}$ uptake at $40 \mathrm{mg} \mathrm{P} \mathrm{kg}^{-1}$ soil. This same genotype at $40 \mathrm{mg} \mathrm{P} \mathrm{kg}^{-1}$ soil had the highest shoot dry weight, total biomass, was the second highest in root dry weight as well as nodules dry weight. These suggest that the genotype had good response to P application and would be efficient in improving soil fertility through nitrogen fixation.

\section{References}

Abelson, P. H. (1999). A potential phosphate crisis. Science, 283 (5410), p. 2015. http://dx.doi.org/10.1126/science.283.5410.2015.

Adetunji, M. T. (1995). Equilibrium phosphate concentration as an estimate of phosphate needs of maize in some tropical Alfisols. Tropical Agriculture, 72: 285- 289.

Agboola, A. A. \& Obigbesan, G. O. (1977). Effect of different sources and levels of P on the performance and P uptake of Ife-Brown variety of cowpea. Ghana Journal of Agriculture Science, 10 (1): 71 - 75.

Ankomah, A. B., Zapata, G., Hardason \& Danso, S. K. O. (1995). Yield, nodulation, and $\mathrm{N}_{2}$ fixation by cowpea cultivars at different phosphorus levels. Biology and Fertility of Soils, 22: 10-15.

Atkinson, D. (1991). Influence of root system morphology and development on the need for fertilizers and the efficiency of use. In Plant Roots: The Hidden Half. Y. Waisel and U. Kafkaki. Pp 411-451. Marcel DEKKER, Inc. New York, Basel, Hongkong.

Basu, P. Zhang, Y. J. Lynch, J. P. and Brown, M. K. (2007). Ethylene modulates genetic, positional, and nutritional regulation of root plagiogravitropism Functional Plant Biology, 34: 41-51. http://dx.doi.org/10.1071/FP06209.

Brynes, B. H. \& Bumb, B. L. (1998). Population growth, food production and nutrient requirements In Nutrient Use in Crop Production. Ed. Z. Rengel. Food Product Press, New York, London.

Gardner, W. \& Boundy, K. A. (1983). The acquisition of phosphorus by Lupinus albus L. IV. The effect of intercropping wheat and white lupin on the growth and mineral composition of the two species. Plant and Soil, 70: 391-402.

Hogh-Jensen, H., Schjoerring, J. K. \& Soussana, J. F. (2002). The influence of phosphorus deficiency on growth and nitrogen fixation of white clover plants. Ann. Bot., 90: 745-753, http://dx.doi.org/10.1093/aob/mcf260.

Holford, I. C. P. (1997). Soil phosphorus, its measurement and its uptake by plants. Australian. Journal of Soil Research, 35: 227-239.

Horst, W. J., Kamh, M., Jibrin, J. M. \& Chude, V. O. (2001). Agronomic measures for increasing P availability to crops. Plant and Soil, 237: 211-223.

Jain, V.K., Chauhan, Y. S. \& Jain, P. C. (1986). Effect of different doses of phosphorus on growth, yield, and quality of cowpea(Vigna unguiculata (L) Walp.). Madras Agricultural Journal, 73(4):199-202.

Kolawole, G. O., Tinan, G, \& Singh, B. B (2002). Differential response of cowpea lines to application of P fertilizer. In Challenges and Opportunities for Enhancing Sustainable Cowpea production, Edited by Fatokun CA, 
Tarawali SA, Singh BB, Kormawa PM, Tamo M International Institute of Tropical Agriculture (IITA), Ibadan. Nigeria 319-328.

Krasilnikoff, G.; Gahoonia, T. \& Neilsen, N. E. (2003). Variation in phosphorus uptake efficiency by genotypes of cowpea (Vigna unguiculata) due to differences in root and root hair length and induced rhizosphere processes. Plant and Soil, 251: 83-91.

Leon, J. \& Schwang, K. U. (1992). Description and application of a screening method to determine root morphology traits of cereals cultivars. Z. Acker. Pflanzenbau, 169: 128-134.

Luse, R. L., Kang, B. T., Fox, R. L. \& Nangju, D. (1975). Protein quality in grain legumes grown in the lieland humid tropics, with special reference to West Africa. Pages 193-201 in Fertilizer use and protein production.Xith Colloquim,International Potash Institute, 1975. Ronne-Born-holm, Denmark.

Marschner, H. (1998). Role of root growth, arbuscular mycorrhiza and root exudates for the efficiency in nutrient acquisition. Field Crop Research, 56: 203-207. http://www.linkinghub.elsevier.com/retrieve/pii/S0378429097001317

Mokwunye, A.U., Chien, S.H., \& Rhodes, E. (1986). Phosphorus reaction with tropical Africansoils. Pp 253-281 In Management of nitrogen and phosphorus fertilizers in sub-saharan Africa, edited by A.U. Mokwunye and P.L.G. Vlek. Martinus Nijhoff Publishers, Dordreccht, The Netherlands.

Nuruzzaman, M., Lambers, H., Bolland, M. D. A. \& Veneklaas, E. J. (2005). Phosphorus benefits of different legume crops to subsequent wheat grown in different soils of Western Australia. Plant and Soil, 271: 175-187. http://dx.doi.org/10.1007/s11104-004-2386-6

Okeleye, K.A. \& Okelana, M.A.O. (1997). Effect of phosphorus fertilizer on nodulation, growth and yield of cowpea (Vigna unguiculata) varieties. Indian Journal of Agricultural Sciences, 67(1): 10-12.

Roman-Aviles, B., Snapp, S.S. \& Kelly, J.D. (2004). Assessing root traits associated with root rot resistance in common bean. Field Crops Research, 86: 147-156.

Romer, W.J., Augustin, J \& Schilling, G. (1988). The relationship between phosphate absorption and root-length in nine wheat cultivars. Plant and Soil, 111: 199-201.

Sanginga, N., Lassa, O. \& Singh, B.B. (2000). Phosphorus use efficiency and nitrogen balance of cowpea breeding lines in a low P soil of the derived savanna zone in West Africa. Plant and Soil, 220: 119-128.

Singh, B.B. (1999). Breeding for improved quality. IITA Annual Report 1999. Project 11. Pages 31-32.

Tenebe, V. A., Yusuf, Y., Kaigama, B.K. \& Aseime, I.O.E. (1995). The effects of sources and levels of phosphorus on the growth and yield of cowpea (Vigna unguiculata (L.) Walp) varieties. Tropical Science, 35: 223-228.

Table 1. Characteristics of the subsoil at a depth of between 20 and $40 \mathrm{~cm}$

\begin{tabular}{|c|c|}
\hline Soil properties & Value \\
\hline $\mathrm{pH}\left(\mathrm{H}_{2} \mathrm{O}\right)$ & 5.2 \\
\hline $\mathrm{OM}(\mathrm{g} / \mathrm{kg})$ & 9.50 \\
\hline $\mathrm{N}(\mathrm{g} / \mathrm{kg})$ & 0.57 \\
\hline $\mathrm{P}(\mathrm{mg} / \mathrm{kg})$ & 1.61 \\
\hline $\mathrm{Ca}(\mathrm{cmol} / \mathrm{kg})$ & 1.28 \\
\hline $\mathrm{Mg}(\mathrm{cmol} / \mathrm{kg})$ & 0.38 \\
\hline $\mathrm{K}(\mathrm{cmol} / \mathrm{kg})$ & 0.15 \\
\hline $\mathrm{Na}(\mathrm{cmol} / \mathrm{kg})$ & 0.12 \\
\hline $\mathrm{Zn}(\mathrm{mg} / \mathrm{kg})$ & 3.82 \\
\hline $\mathrm{Cu}(\mathrm{mg} / \mathrm{kg})$ & 2.39 \\
\hline $\mathrm{Mn}(\mathrm{mg} / \mathrm{kg})$ & 93.91 \\
\hline $\mathrm{Fe}(\mathrm{mg} / \mathrm{kg})$ & 53.19 \\
\hline $\mathrm{Sand}(\mathrm{g} / \mathrm{kg})$ & 800 \\
\hline $\mathrm{Clay}(\mathrm{g} / \mathrm{kg})$ & 80 \\
\hline $\mathrm{Silt}(\mathrm{g} / \mathrm{kg})$ & 120 \\
\hline Textural class & Loamy sand \\
\hline
\end{tabular}


Table 2. Shoot and root dry weights of cowpea genotypes as affected by $\mathrm{P}$ application rate under screen house condition at six weeks after sowing

\begin{tabular}{|c|c|c|c|c|c|c|c|c|}
\hline \multirow{3}{*}{ Genotypes } & \multicolumn{4}{|c|}{ Shoot dry weight (g/pot) } & \multirow{2}{*}{\multicolumn{4}{|c|}{$\frac{\text { Root dry weight }(\mathrm{g} / \mathrm{pot})}{\text { P rate }\left(\mathrm{mg} \mathrm{kg}^{-1} \text { soil) }\right.}$}} \\
\hline & \multicolumn{4}{|c|}{ P rate $\left(\mathrm{mg} \mathrm{kg}^{-1}\right.$ soil $)$} & & & & \\
\hline & 0 & 20 & 40 & Mean & 0 & 20 & 40 & Mean \\
\hline IT92KD--405-2 & 1.16 & 1.59 & 1.39 & 1.38 & 0.33 & 0.68 & 0.80 & 0.60 \\
\hline IT93KZ-4-3-1-7 & 1.41 & 1.45 & 1.29 & 1.38 & 0.67 & 0.65 & 0.79 & 0.70 \\
\hline IT85D-3334-1 & 1.33 & 1.75 & 1.91 & 1.66 & 0.53 & 1.11 & 0.61 & 0.75 \\
\hline IT97K-414-5 & 1.31 & 1.58 & 1.59 & 1.49 & 0.41 & 0.47 & 0.45 & 0.44 \\
\hline IT98K-205-9 & 1.73 & 1.04 & 1.94 & 1.57 & 0.49 & 0.66 & 0.78 & 0.64 \\
\hline IT86D-330 & 1.11 & 1.01 & 1.81 & 1.31 & 0.55 & 0.27 & 0.71 & 0.51 \\
\hline IT93K-573-1 & 1.35 & 1.26 & 2.19 & 1.60 & 0.59 & 0.37 & 0.88 & 0.61 \\
\hline IT92KD-279-3 & 0.92 & 1.24 & 1.38 & 1.18 & 0.32 & 0.42 & 0.46 & 0.40 \\
\hline IT93K-2045-29 & 1.07 & 1.56 & 1.67 & 1.43 & 0.33 & 0.65 & 1.23 & 0.74 \\
\hline IT92KD-267-2 & 1.31 & 1.77 & 1.91 & 1.66 & 0.69 & 0.42 & 0.58 & 0.56 \\
\hline Mean & 1.27 & 1.42 & 1.71 & & 0.49 & 0.57 & 0.73 & \\
\hline \multicolumn{9}{|l|}{$L S D$} \\
\hline Genotypes (G) & & 0.39 & & & & 0.31 & & \\
\hline $\mathrm{P}$ rate $(\mathrm{P})$ & & 0.22 & & & & 0.17 & & \\
\hline $\mathrm{G} \times \mathrm{P}$ & & 0.68 & & & & 0.54 & & \\
\hline \multicolumn{9}{|l|}{ ANOVA } \\
\hline Genotypes (G) & & $\mathrm{ns}$ & & & & $\mathrm{ns}$ & & \\
\hline $\mathrm{P}$ rate $(\mathrm{P})$ & & $* * *$ & & & & * & & \\
\hline $\mathrm{G} \times \mathrm{P}$ & & $\mathrm{ns}$ & & & & ns & & \\
\hline
\end{tabular}

ns - not significant $*$ - significant at $\mathrm{p}<0.05 * * *$ - significant at $\mathrm{p}<0.001$

Table 3. Phosphorus application effect on the nodulation of cowpea genotypes under screen house condition at six weeks after sowing

\begin{tabular}{|c|c|c|c|c|c|c|c|c|}
\hline \multirow{3}{*}{ Genotypes } & \multicolumn{4}{|c|}{ Number of nodules } & \multirow{2}{*}{\multicolumn{4}{|c|}{$\begin{array}{l}\text { Nodules dry weight (g/pot) } \\
\text { P rate }\left(\mathrm{mg} \mathrm{kg}^{-1} \text { soil) }\right.\end{array}$}} \\
\hline & \multicolumn{4}{|c|}{$\mathrm{P}$ rate $\left(\mathrm{mg} \mathrm{kg}^{-1}\right.$ soil $)$} & & & & \\
\hline & 0 & 20 & 40 & Mean & 0 & 20 & 40 & Mean \\
\hline IT92KD--405-2 & 5 & 3 & 14 & 8 & 0.001 & 0.008 & 0.027 & 0.012 \\
\hline IT93KZ-4-3-1-7 & 10 & 9 & 9 & 9 & 0.007 & 0.010 & 0.019 & 0.012 \\
\hline IT85D-3334-1 & 4 & 18 & 18 & 14 & 0 & 0.040 & 0.017 & 0.019 \\
\hline IT97K-414-5 & 0 & 8 & 9 & 5 & 0 & 0.002 & 0.011 & 0.004 \\
\hline IT98K-205-9 & 0 & 4 & 7 & 4 & 0 & 0.011 & 0.015 & 0.009 \\
\hline IT86D-330 & 0 & 3 & 24 & 9 & 0 & 0.002 & 0.025 & 0.009 \\
\hline IT93K-573-1 & 7 & 6 & 12 & 8 & 0.004 & 0.002 & 0.031 & 0.013 \\
\hline IT92KD-279-3 & 1 & 3 & 6 & 4 & 0 & 0 & 0.005 & 0.002 \\
\hline IT93K-2045-29 & 5 & 11 & 15 & 10 & 0.001 & 0.010 & 0.025 & 0.012 \\
\hline IT92KD-267-2 & 14 & 5 & 27 & 15 & 0.014 & 0.001 & 0.130 & 0.049 \\
\hline Mean & 5 & 7 & 14 & & 0.003 & 0.009 & 0.031 & \\
\hline \multicolumn{9}{|l|}{$L S D$} \\
\hline Genotypes $(\mathrm{G})$ & & 10 & & & & 0.026 & & \\
\hline $\mathrm{P}$ rate $(\mathrm{P})$ & & 5 & & & & 0.014 & & \\
\hline $\mathrm{G} \times \mathrm{P}$ & & 17 & & & & 0.040 & & \\
\hline \multicolumn{9}{|l|}{ ANOVA } \\
\hline Genotypes (G) & & $\mathrm{ns}$ & & & & $*$ & & \\
\hline $\mathrm{P}$ rate $(\mathrm{P})$ & & $* *$ & & & & $* * *$ & & \\
\hline $\mathrm{G} \times \mathrm{P}$ & & $\mathrm{ns}$ & & & & $*$ & & \\
\hline
\end{tabular}

ns - not significant

** - significant at $(\mathrm{p}<0.01)$

* - significant at $(\mathrm{p}<0.05) \quad * * *$ - significant at $(\mathrm{p}<0.001)$ 
Table 4. Phosphorus application effect on the root architecture of cowpea genotypes under screen house condition at six weeks after sowing

\begin{tabular}{|c|c|c|c|c|c|c|c|c|}
\hline & \multicolumn{4}{|c|}{ Number of whorls } & \multicolumn{4}{|c|}{ Total number of roots } \\
\hline Genotypes & \multicolumn{4}{|c|}{$\mathrm{P}$ rate $\left(\mathrm{mg} \mathrm{kg}^{-1}\right.$ soil $)$} & \multicolumn{4}{|c|}{$\mathrm{P}$ rate $\left(\mathrm{mg} \mathrm{kg}^{-1}\right.$ soil $)$} \\
\hline & 0 & 20 & 40 & Mean & 0 & 20 & 40 & Mean \\
\hline IT92KD--405-2 & 4 & 4 & 4 & 3.89 & 10 & 8 & 8 & 8.39 \\
\hline IT93KZ-4-3-1-7 & 4 & 3 & 4 & 3.44 & 8 & 6 & 9 & 7.44 \\
\hline IT85D-3334-1 & 5 & 4 & 4 & 4.39 & 10 & 9 & 9 & 9.28 \\
\hline IT97K-414-5 & 4 & 3 & 4 & 3.61 & 8 & 7 & 8 & 7.61 \\
\hline IT98K-205-9 & 4 & 4 & 4 & 3.94 & 9 & 8 & 8 & 8.44 \\
\hline IT86D-330 & 4 & 4 & 4 & 3.72 & 8 & 8 & 9 & 8.33 \\
\hline IT93K-573-1 & 3 & 3 & 3 & 3.11 & 7 & 6 & 8 & 6.61 \\
\hline IT92KD-279-3 & 3 & 3 & 2 & 2.56 & 6 & 6 & 4 & 5.28 \\
\hline IT93K-2045-29 & 2 & 3 & 3 & 2.67 & 4 & 8 & 5 & 5.72 \\
\hline IT92KD-267-2 & 3 & 2 & 3 & 2.67 & 7 & 5 & 6 & 5.72 \\
\hline Mean & 3.55 & 3.23 & 3.42 & & 7.65 & 6.82 & 7.38 & \\
\hline$L S D$ & & & & & & & & \\
\hline Genotypes (G) & & 0.59 & & & & 1.39 & & \\
\hline $\mathrm{P}$ rate $(\mathrm{P})$ & & 0.32 & & & & 0.77 & & \\
\hline $\mathrm{G} \times \mathrm{P}$ & & 1.02 & & & & 2.43 & & \\
\hline$A N O V A$ & & & & & & & & \\
\hline Genotypes $(\mathrm{G})$ & & $* * *$ & & & & $* * *$ & & \\
\hline $\mathrm{P}$ rate $(\mathrm{P})$ & & $\mathrm{ns}$ & & & & $*$ & & \\
\hline $\mathrm{G} \times \mathrm{P}$ & & ns & & & & $*$ & & \\
\hline
\end{tabular}

ns - not significant $*$ - significant at $(\mathrm{p}<0.05) \quad * * *$ - significant at $(\mathrm{p}<0.001)$

Table 5. Effects of P Application on the Total Biomass of Cowpea Genotypes under Screen house condition at six weeks after planting

\begin{tabular}{|l|c|c|c|c|}
\hline & \multicolumn{4}{|c|}{ Total biomass $(\mathrm{g} / \mathrm{pot})$} \\
\hline & 0 & 20 & 40 & P rate $\left(\mathrm{mg} \mathrm{kg}^{-1}\right)$ soil \\
\hline Genotypes & 1.48 & 2.27 & 2.19 & 1.98 \\
\hline IT92KD--405-2 & 2.08 & 2.10 & 2.09 & 2.09 \\
\hline IT93KZ-4-3-1-7 & 1.87 & 2.86 & 2.52 & 2.42 \\
\hline IT85D-3334-1 & 1.72 & 2.05 & 2.04 & 1.94 \\
\hline IT97K-414-5 & 2.22 & 1.70 & 2.71 & 2.21 \\
\hline IT98K-205-9 & 1.66 & 1.27 & 2.52 & 1.82 \\
\hline IT86D-330 & 1.93 & 1.63 & 3.07 & 2.21 \\
\hline IT93K-573-1 & 1.24 & 1.66 & 1.85 & 1.58 \\
\hline IT92KD-279-3 & 1.39 & 2.22 & 2.90 & 2.17 \\
\hline IT93K-2045-29 & 2.00 & 2.19 & 2.48 & 2.23 \\
\hline IT92KD-267-2 & 1.76 & 1.99 & 2.44 & \\
\hline Mean & & & & \\
\hline & & & & \\
\hline LSD & & 0.49 & & \\
\hline Genotype (G) & & 0.27 & & \\
\hline P rate (P) & & & & \\
\hline G $\times$ P & & $* * *$ & & \\
\hline ANOVA & & $\mathrm{ns}$ & & \\
\hline Genotype (G) & & &
\end{tabular}

ns - not significant

$* * *$ - significant at $(\mathrm{p}<0.001)$ 
Table 6. Phosphorus application effect on $\mathrm{N}$ and $\mathrm{P}$ uptake under screen house condition at six weeks after sowing

\begin{tabular}{|c|c|c|c|c|c|c|c|c|}
\hline & \multicolumn{4}{|c|}{ N uptake } & \multicolumn{4}{|c|}{ P uptake } \\
\hline \multirow[t]{2}{*}{ Genotypes } & \multicolumn{4}{|c|}{$\mathrm{P}$ rate $\left(\mathrm{mg} \mathrm{kg}^{-1}\right.$ soil $)$} & \multicolumn{4}{|c|}{ P rate $\left(\mathrm{mg} \mathrm{kg}^{-1}\right.$ soil $)$} \\
\hline & 0 & 20 & 40 & Mean & 0 & 20 & 40 & Mean \\
\hline IT92KD--405-2 & 3.99 & 5.16 & 4.29 & 4.48 & 0.13 & 0.27 & 0.25 & 0.22 \\
\hline IT93KZ-4-3-1-7 & 2.41 & 4.47 & 3.70 & 3.53 & 0.10 & 0.19 & 0.21 & 0.16 \\
\hline IT85D-3334-1 & 3.66 & 4.66 & 4.59 & 4.30 & 0.15 & 0.23 & 0.18 & 0.19 \\
\hline IT97K-414-5 & 4.83 & 4.86 & 5.06 & 4.92 & 0.18 & 0.28 & 0.20 & 0.22 \\
\hline IT98K-205-9 & 4.92 & 2.94 & 4.98 & 4.28 & 0.18 & 0.17 & 0.29 & 0.21 \\
\hline IT86D-330 & 3.53 & 3.63 & 5.14 & 4.10 & 0.13 & 0.13 & 0.30 & 0.19 \\
\hline IT93K-573-1 & 4.39 & 3.77 & 5.92 & 4.70 & 0.17 & 0.24 & 0.35 & 0.26 \\
\hline IT92KD-279-3 & 3.16 & 3.40 & 4.20 & 3.59 & 0.14 & 0.16 & 0.25 & 0.18 \\
\hline IT93K-2045-29 & 3.91 & 4.46 & 4.45 & 4.27 & 0.14 & 0.24 & 0.25 & 0.21 \\
\hline IT92KD-267-2 & 4.68 & 4.63 & 5.69 & 5.00 & 0.15 & 0.18 & 0.28 & 0.20 \\
\hline Mean & 3.95 & 4.20 & 4.80 & & 0.15 & 0.21 & 0.26 & \\
\hline \multicolumn{9}{|l|}{$L S D$} \\
\hline Genotype (P) & & 0.67 & & & & & 0.05 & \\
\hline $\mathrm{P} \operatorname{rate}(\mathrm{P})$ & & 0.37 & & & & & 0.03 & \\
\hline $\mathrm{G} \times \mathrm{P}$ & & 1.16 & & & & & 0.08 & \\
\hline \multicolumn{9}{|l|}{ ANOVA } \\
\hline Genotype (P) & & $* * *$ & & & & & * & \\
\hline $\mathrm{P}$ rate $(\mathrm{P})$ & & *** & & & & & $* * *$ & \\
\hline $\mathrm{G} \times \mathrm{P}$ & & ** & & & & & ** & \\
\hline
\end{tabular}

* - significant at $(\mathrm{p}<0.05) \quad * *$ - significant at $(\mathrm{p}<0.01) \quad * * *$ - significant at $(\mathrm{p}<0.001)$

Table 7. Correlation Coefficient Relationship between Shoot and Root Dry Weight, Total Biomass, Number of Nodules, Nodules Dry Weight, N and P Uptake

\begin{tabular}{|c|c|c|c|c|c|c|c|}
\hline & $\begin{array}{l}\text { Shoot dry } \\
\text { weight }\end{array}$ & \begin{tabular}{|l} 
Root dry \\
weight
\end{tabular} & \begin{tabular}{|l} 
Total \\
Biomass \\
\end{tabular} & $\begin{array}{l}\text { Number of } \\
\text { nodules }\end{array}$ & $\begin{array}{l}\text { Nodules dry } \\
\text { weight }\end{array}$ & $\begin{array}{l}\mathrm{N} \\
\text { uptake }\end{array}$ & \begin{tabular}{|l}
$\mathrm{P}$ \\
uptake
\end{tabular} \\
\hline Shoot dry weight & 1 & & & & & & \\
\hline Root dry weight & 0.19 & 1 & & & & & \\
\hline Total biomass & $0.84 * * *$ & $0.70^{* * *}$ & 1 & & & & \\
\hline $\begin{array}{l}\text { Number of } \\
\text { nodules }\end{array}$ & $0.34 * *$ & 0.10 & $0.30 * *$ & 1 & & & \\
\hline $\begin{array}{l}\text { Nodules dry } \\
\text { weight }\end{array}$ & $0.24 *$ & 0.08 & $0.22 *$ & $0.44 * * *$ & 1 & & \\
\hline N uptake & $0.34 * *$ & 0.14 & $0.32 * *$ & $0.30^{* *}$ & $0.31 * *$ & 1 & \\
\hline P uptake & $0.36^{* * *}$ & 0.20 & $0.37 * * *$ & $0.27 *$ & $0.37 * * *$ & $0.64 * * *$ & 1 \\
\hline
\end{tabular}

*- significant at $\mathrm{p}<0.05 * *$ - significant at $\mathrm{p}<0.01 * * *$ - significant at $\mathrm{p}<0.001$ 
Table 8. Correlation Coefficient Relationship between N and P Uptake, Number of Root Whorl and Total Number of Roots

\begin{tabular}{|c|c|c|c|c|}
\hline & N Uptake & P Uptake & Whorls & Total root \\
\hline N Uptake & 1.000 & & & \\
\hline P Uptake & $0.73^{* * *}$ & 1.000 & & \\
\hline Whorls & -0.12 & -0.13 & 1.000 & \\
\hline Total root & 0.04 & -0.05 & $0.89 * * *$ & 1.000 \\
\hline
\end{tabular}

$* * *$ - significant at $\mathrm{p}<0.001$

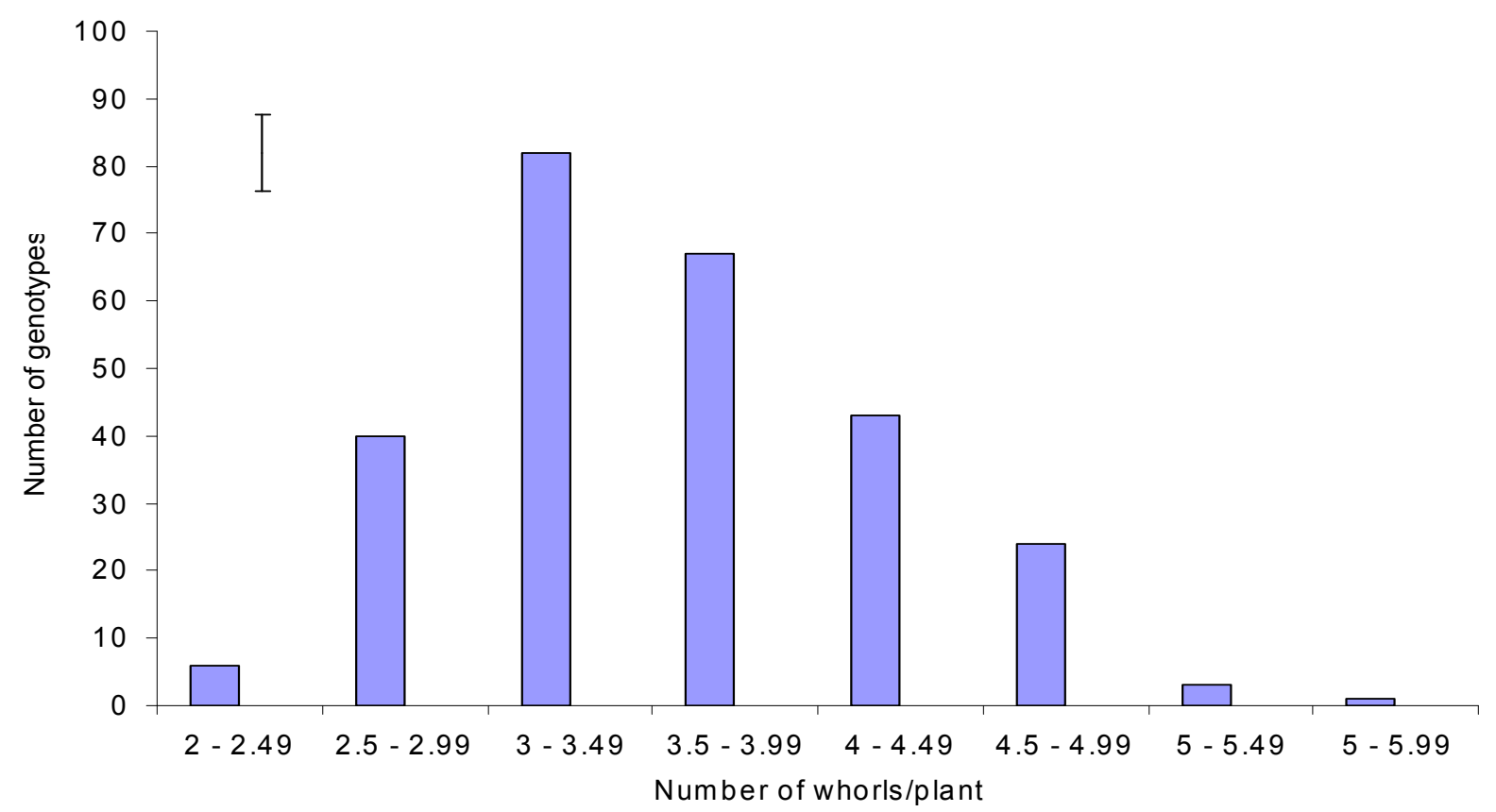

Figure 1. Variation in number of root whorls among 300 cowpea genotypes

Bar represents standard error. 